\title{
Spanskesyken og kinematografene
}

\begin{abstract}
Spanskesyken skyllet over Norge i tre bølger fra sommeren 1918 til mars 1919 og spredde seg raskt over store deler av landet. Ikke engang Svalbard ble spart. Sykdommen tok $13000-15000$ liv, og skapte mye angst og bekymring (1). I dette innlegget er det Magnus Meklenborg Geirsvold (1867-1936), stadsfysikus i Bergen, som beklager seg over hvordan smittevernet blir gjennomført ulikt på de forskjellige steder og den usikkerhet dette medfører blant publikum. Han etterlyser en «gjennemført organisation og planmæssig ledelse». Som mulige tiltak foreslår han utarbeiding av korte veiledninger for publikum til gratis utdeling, trykte direktiver til legene, og konsekvent og regelmessig informasjon til dagspressen for at de skal få de «tilgjængelige faktiske oplysninger i «knap form»; man må ikke la «dagspressen ta ledelsen». Ikke minst etterlyste han systematisk kartlegging av utbredelse, omfang og sosiale forhold hos dem som hadde fått sykdommen. Men mest er han nok opprørt over alle de urimelige tiltak som treffes, og den unødvendige angst som skapes i befolkningen (Tidsskr Nor Lægeforen 1918; 38: 1026-8). Det siste lyder ikke helt fremmed for oss som har stått midt oppe i svineinfluensautbruddet.
\end{abstract}

\section{«Den spanske syke» og det offentlige sundhetsvæsen}

\author{
Av M. Geirsvold, stadsfysikus, Bergen.
}

Det har været en gaske usedvanlig «paakjending», som sundhetsmyndigheterne har været gjenstand for under denne siste epidemi. Især har det gaat ut over sundhetscheferne i de større byer Stockholm, Kristiania og Bergen, fordi de ikke paa trods av al epidemiologisk erfaring og alle nødvendige konsekvenser har fundet at burde lukke skoler og offentlige sammenkomster for at stille folkemeningen tilfreds - kaste Jonas over bord for at stille stormen. Særlig har kinematograferne været gjenstand for et intenst had, skjønt man skulde tro, at de maatte være publikums specielle yndlinger. Men jeg kan ikke erindre, at jeg i den svære bunke avisutklip, som jeg har samlet om epidemien, har set en eneste stemme til deres forsvar. De er uten videre stemplet som «smittebuler» av den værste sort, $\mathrm{i}$ hvis mørke bakterier yngler som sop og erhverver en fantastisk virulens og smitteevne. Uttalelserne stammer ofte fra personer, som ikke har sat sin fot der paa aar og dag. Ogsa læger har deltat i dette hylekor. [---]

Men epidemien gaar i sin ondartede form som et epidemisk uveir over land og strand til de ytterste skjær og de mest avsidesliggende fjelddaler. Det er intet under, at den store masse er opskræmt. Har sundhetsvæsenet i de store byer været "lunkent og indifferent» saa har til gjengiæld de mindre byer været saa meget mere «aktive». De har lukket og forbudt over en lav sko. Og publikum spør forbauset: hvorfor skal ikke «forholdsreglerne» være nogenlunde de samme over hele landet? Hvorfor er det mere unyttig at «lukke» i Kristiania og Bergen end f.eks. i Arendal og Fredriksstad? Rigtignok har Medicinaldirektøren med støtte av alt, hvad der heter hygienisk erfaring og autoritet i vort land, karakterisert slike foranstaltninger som fuldstændig «nytteløse». Men publikum indvender - hvorfor gjør man da dette saa mange andre steder baade herhjemme og i utlandet? Er vi da saa meget klokere her hos os? Naar man kan stoppe nærsagt en hvilkensomhelst farsot fra pest, kopper og kolera til tyfus og difteri - hvorfor gir man pludselig op likeovenfor en farsot saa ondartet som «den spanske» kan være? 